\title{
How small you can go: Factors limiting body miniaturization in winged insects with a review of the pantropical genus Discheramocephalus and description of six new species of the smallest beetles (Pterygota: Coleoptera: Ptiliidae)
}

\author{
VASILY V. GREBENNIKOV \\ Entomology Research Laboratory, Ontario Plant Laboratories, Canadian Food Inspection Agency, K.W. Neatby Bldg., \\ 960 Carling Avenue, Ottawa, Ontario K1A 0C6, Canada; e-mail: grebennikovv@inspection.gc.ca \\ Institut für Spezielle Zoologie und Evolutionbiologie, Friedrich-Schiller-Universität Jena, Erbertstraße 1, D-07743 Jena, German y
}

Key words. Body size, miniaturization, C-value, Insecta, Pterygota, Coleoptera, Ptiliidae, Discheramocephalus, Hymenoptera, Platygastridae, Errolium, egg-parasitoids, smallest insect, description, morphology, anatomy, histology

\begin{abstract}
The recently described and originally monotypic genus Discheramocephalus Johnson, 2007 from the Solomon Islands is revised. Six new species are described, illustrated and keyed: Discheramocephalus brucei sp. n. (Cameroon), D. elisabethae sp. n. (Cameroon), D. mikaeli sp. n. (Tanzania), D. stewarti sp. n. (Bolivia), D. jarmilae sp. n. (Bolivia), D. minutissimus sp. n. (Indonesia). Adults of D. minutissimus have a body length of about $400-426 \mu \mathrm{m}$, which is at the lower limit among non-eggparasitoid insects. Evidence is provided that an egg size large enough to produce a viable larva is the main factor limiting miniaturisation of female insects. Females and males of egg-parasitoids are able to overcome the $400 \mu \mathrm{m}$ threshold and reach limits of 180 $\mu \mathrm{m}$ and $130 \mu \mathrm{m}$, respectively. Brain size is likely the second most important factor limiting miniaturisation in insects.
\end{abstract}

\section{INTRODUCTION}

Miniaturisation in multicellular animals, or evolution of extremely small body size, is a remarkable natural phenomenon. As they become smaller, organisms gain access to new niches, acquire new food sources and avoid predation. Miniaturisation is among the key reasons for extensive radiation in several evolutionary successful lineages where animals have less-than-the-average body size, e.g. shrews (Soricomorpha: Soricidae) in mammals, hummingbirds (Apodiformes: Trochilidae) in birds and featherwing beetles in insects. There are, however, limiting factors preventing organisms from becoming indefinitely small.

Physical body size is the most commonly used concept of "size" in eukaryote organisms. In multicellular metazoans there are at least two other parameters, both representing different concepts of what "size" might mean in biology. Metazoans are made up of cells that also have their own linear limits (Faisal et al., 2005). Genome size of a haploid nucleus (C-value) is yet another way of measuring "size" (Johnston et al., 2004; Gregory, 2007). There is apparently a positive correlation between genome and cell size (Gregory, 2001), and, likely, between body size and cell size (Rensch, 1948). Thus the true concept of "biological" size of a multicellular organism is a significantly more complex issue than just physical body size (Hanken \& Wake, 1993).

Attention to animal miniaturisation has focused mainly on vertebrates (Alexander, 1996) or on individual insect organs such as the brain (Beutel et al., 2005). Different factors named as those limiting the process of miniaturisation in animals include disruption of thermoregulation or respiration, water loss, difficulty to fly, water surface tension (Novotny \& Wilson, 1997), cell and tissue size, and egg or brain size (Polilov, 2005).

The goal of this paper is to revise the genus Discheramocephalus Johnson, 2007 of minute featherwing beetles (Ptiliidae; see Hall, 2005, for a recent overview of the family), whose species are among the smallest non-eggparasitoid insects known. Evidence is presented suggesting that egg size is the main factor limiting body miniaturization in female winged insects, while brain size might be the second most important factor. Other factors, such as relatively greater air viscosity and weight reduction of articulated appendages and their muscles, are briefly considered. Different biological scenarios related to the phenomenon of body size miniaturization in Pterygota are discussed.

\section{MATERIAL AND METHODS}

Beetles were extracted from forest floor leaf litter or collected by flight intercept traps (FIT). Leaf litter was pre-sifted to separate the fine fraction containing micro-arthropods, and then placed in Winkler or Berlese funnels to extract small invertebrates. Captured animals were preserved in $70 \%$ ethanol and subsequently sorted under a dissecting microscope. Beetles were later removed from ethanol, cleared in hot $10 \% \mathrm{KOH}$ solution and mounted on microscope slides in Euparal. One specimen per species was glued by the dorsal side of its abdomen to the point of an entomological pin. This pin was inserted into a horizontally-oriented holder in a scanning electron microscope and rotated at 360 degrees around its axis for different views of the specimen. Two specimens of $D$. brucei were dehydrated in gradient solutions of acetone and embedded in epoxy resin for serial sectioning at $1 \mu \mathrm{m}$ on a Leica RM 2165 rotation microtome and stained with methylene blue and acid fuchsin. Transmitted light microscopy images were taken on a compound microscope with attached Nikon digital camera; those using 
scanning electron microscopy (SEM) were taken of uncoated specimens with a Philips XL30 ESEM. SEM specimens were measured using their images with a superimposed scale generated by the attached computer; specimens on microscope slides were projected through a camera lucida on a previously projected image of a $1000 \mu \mathrm{m}$ scale subdivided into one hundred 10 $\mu \mathrm{m}$-long increments. Images of free or whole-mounted beetles were captured by a digital camera and then assembled in Photoshop onto a single plate. Some images were captured at different focal depths to create a combined image with the maximum depth of focus using CombineZ5 software (Hadley, 2006).

All specimens dealt with in this work, including types of the new species (unless otherwise stated), are stored in the Canadian National Collection of Insects, Arachnids and Nematodes, Ottawa, Canada (CNCI). Most of the terms used in this paper are those generally adopted for Ptiliidae (see, for example, Sörensson, 1997). Terms "mesoventer" and "metaventer" are used, however, for the misapplied terms "mesosternum" and "metasternum" (as explained in Lawrence, 1999); "meso"- and "metasternal lines" of Ptiliidae are therefore called "meso"- and "metaventral" lines.

\section{Genus Discheramocephalus Johnson, 2007}

Discheramocephalus Johnson, 2007: 223.

Type species. Discheramocephalus semisulcatus Johnson, 2007, by original designation.

Diagnosis. Members of this genus are easily distinguished from all other Ptiliidae by having a deep transverse groove on head behind eyes, which crosses dorsal surface of head (Figs 4,20), and extends laterally to ventral surface (Figs 9, 22). Possession of a transverse row of two or more deep cavities on sternite VIII is unique among Ptiliidae (Figs 13, 92-98). Species of Discheramocephalus also have the following unique character combination: mesoventral keel with deep, horizontally oriented fossa on each side (Fig. 10); mesoventer with deep and vertically oriented fossa on each anterior corner (Fig. 11); pronotum with at least two deep longitudinal grooves (Figs 1, 16, 25, 37, 46, 55); metacoxae transverse and contiguous (Fig. 3).

Description (these characters, including "absent" characters, are standardized to the format used in generic descriptions in a more inclusive taxonomic treatment of a new tribe of Ptiliidae, which includes the genus Discheramocephalus; see Grebennikov, 2008). Body between pronotum and elytra in dorsal view constricted; body behind pronotum not swollen laterally and vertically; longitudinally oriented micro-ridges on ventral surface of prothorax present; elytral setae forming seven or eight longitudinal rows; transversely oriented depression behind eyes present as groove extending laterally and ventrally; transverse band of 100-200 small punctures on head behind eyes absent; apical antennomere not dumbbell-shaped; longitudinal depressions on labrum absent or present; posterior edge of pronotum at middle concave; depressions on pronotum present as grooves at least half as long as pronotum or ornamented with varying number of longitudinal furrows (type species only); longitudinal keel on scutellum present, sharp, about as long as scutellum; transverse row of round punctures on base of elytra and scutellum absent; two fossae on scutellum absent; hind wings present; meso-metaventral suture between mesocoxae not visible externally; mesometaventral suture laterally of mesocoxae not visible externally, present as internal thickening of cuticle; posteriorly pointed serration along meso-metaventral suture laterally of mesocoxae absent; metaventral longitudinal lateral lines absent; horizontal perforation of mesoventral keel round and transparent in lateral view; mesoventer without transverse grooves; middle of alacrista of metathorax without setae along margins; metacoxae transverse, contiguous, separated by about $1 / 15$ of metaventral width; posteriorly oriented projection of metaventral plate between metacoxae without two lateral teeth; transversely oriented group of about 50-70 closely adjacent round micropores along posterior edge of tergite VIII absent; cavities on abdominal sternum VIII present; single elongate internal sclerite alongside aedeagus present (Figs 75, 93-98); spermatheca weakly developed and nonsclerotised except for sperm pump (Fig. 99), markedly similar in shape in all species.

Composition and geographical distribution. Johnson (2007) described this genus based on a new species from the Solomon Islands and mentiond that "...undescribed species are known to me from Sri Lanka, Madagascar, Congo and Brazil...”. Dybas (1980) illustrated an undescribed congeneric species from Florida and referred to this (then undescribed) genus as "widespread tropical". I saw undescribed species of Discheramocephalus from Australia (Queensland) and Madagascar. The six new species are from Bolivia, Cameroon, Tanzania and Indonesia. These data suggest that Discheramocephalus is a speciose and pantropical genus.

Monophyly and phylogenetic relationships. The genus Discheramocephalus is most likely a monophyletic group because both the deep transverse groove on head behind eyes (Fig. 9) and the transverse row of two or more deep cavities on sternite VIII (Figs 93-98) are unique among Ptiliidae and not known to occur in its sister-family Hydraenidae. Johnson (2007) suggested that the genus Millidium Motschulsky, 1855 might be its closest relative. Our phylogenetic analysis (Grebennikov, 2008) suggests that among known Ptiliidae taxa, Discheramocephalus is most closely related to, or derives from within, the genus Skidmorella Johnson, 1971 from the tropical and subtropical parts of the Oriental zoogeographical region. These two taxa are hypothesised to form a monophyletic group supported by presumably synapomorphic presence of deep longitudinal furrows on pronotal disk, although superficially similar and likely nonhomologous pronotal grooves also occur in other Ptiliidae, such as Millidium Motschulsky, 1855 and some Ptilium Gyllenhal, 1827.

Bionomics. All specimens of Discheramocephalus examined were collected in tropical forests either by flight intercept traps or by sifting leaf litter. 

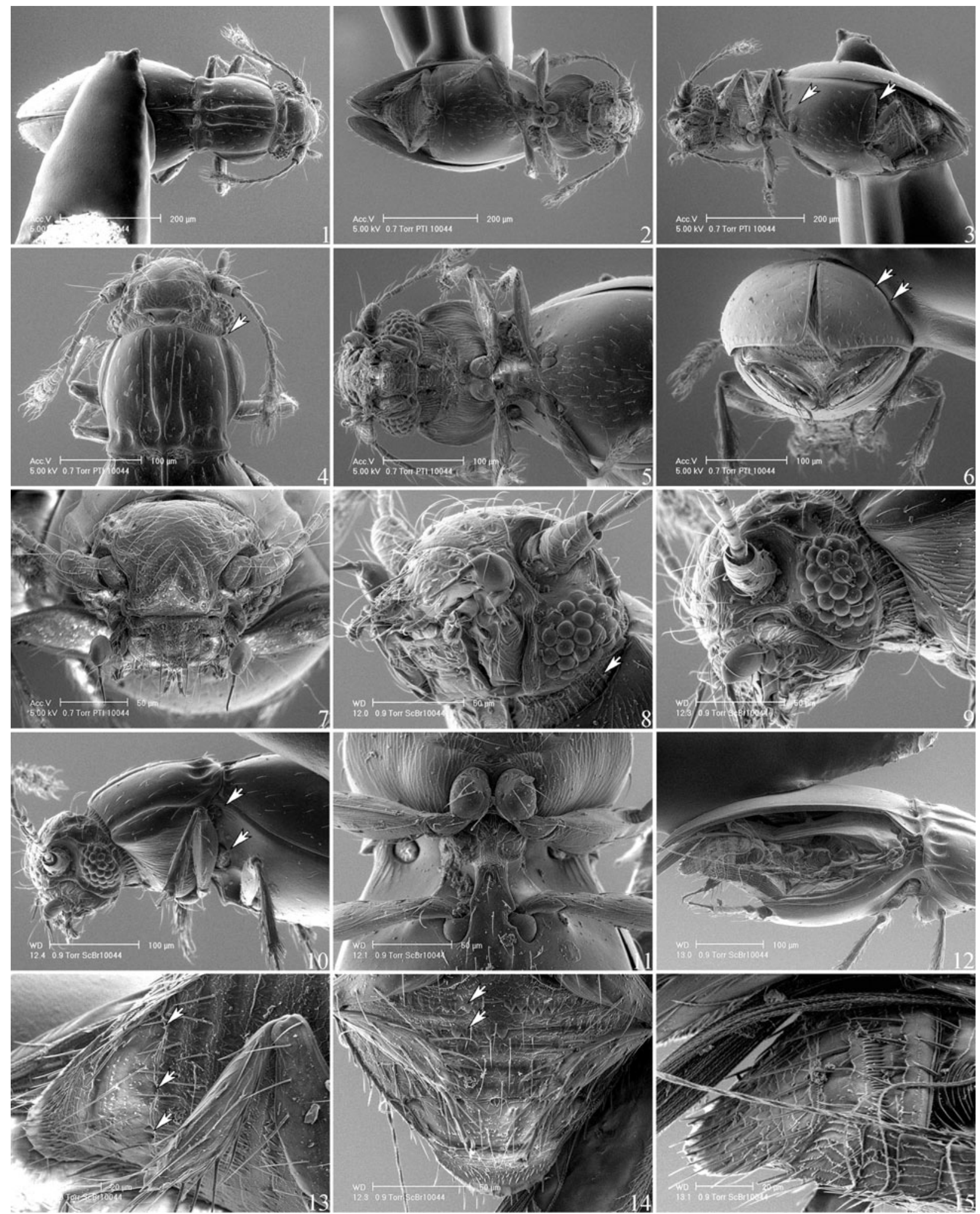

Figs 1-15. Discheramocephalus brucei sp. n. from Cameroon, paratypes, scanning electron microscopy images. 1 - habitus, dorsal view; 2 - habitus, ventral view; 3 - habitus, left ventro-lateral view (left arrow indicates lack of visible meso-metasternal suture, right arrow indicate markedly transverse metacoxae); 4 - anterior half of body, dorsal view (arrow indicates transverse postocellar groove); 5 - anterior half of body, ventral view; 6 - abdomen, posterior view (arrows indicate elytral setae arranged in longitudinal rows); 7 - head, frontal view; 8 - head, left latero-ventral view (arrow indicates transverse postocellar groove); 9 - head, left lateral view; 10 - anterior half of body, left lateral view (upper arrow indicates vertical fossa in anterior corner of mesoventer, lower arrow indicates horizontal fossa in mesoventral keel); 11 - attachment of fore- and middle legs to the body showing mesoventral keel, ventral view; 12 - posterior half of body, right elytron removed, right lateral view; 13 - abdomen, right latero-ventral view (arrows indicate three of five cavities on abdominal sternite VIII); 14 - abdomen, ventral view (arrows indicate transverse rows of cuticular serration); 15 - abdomen, right elytron removed, right dorso-lateral view. 

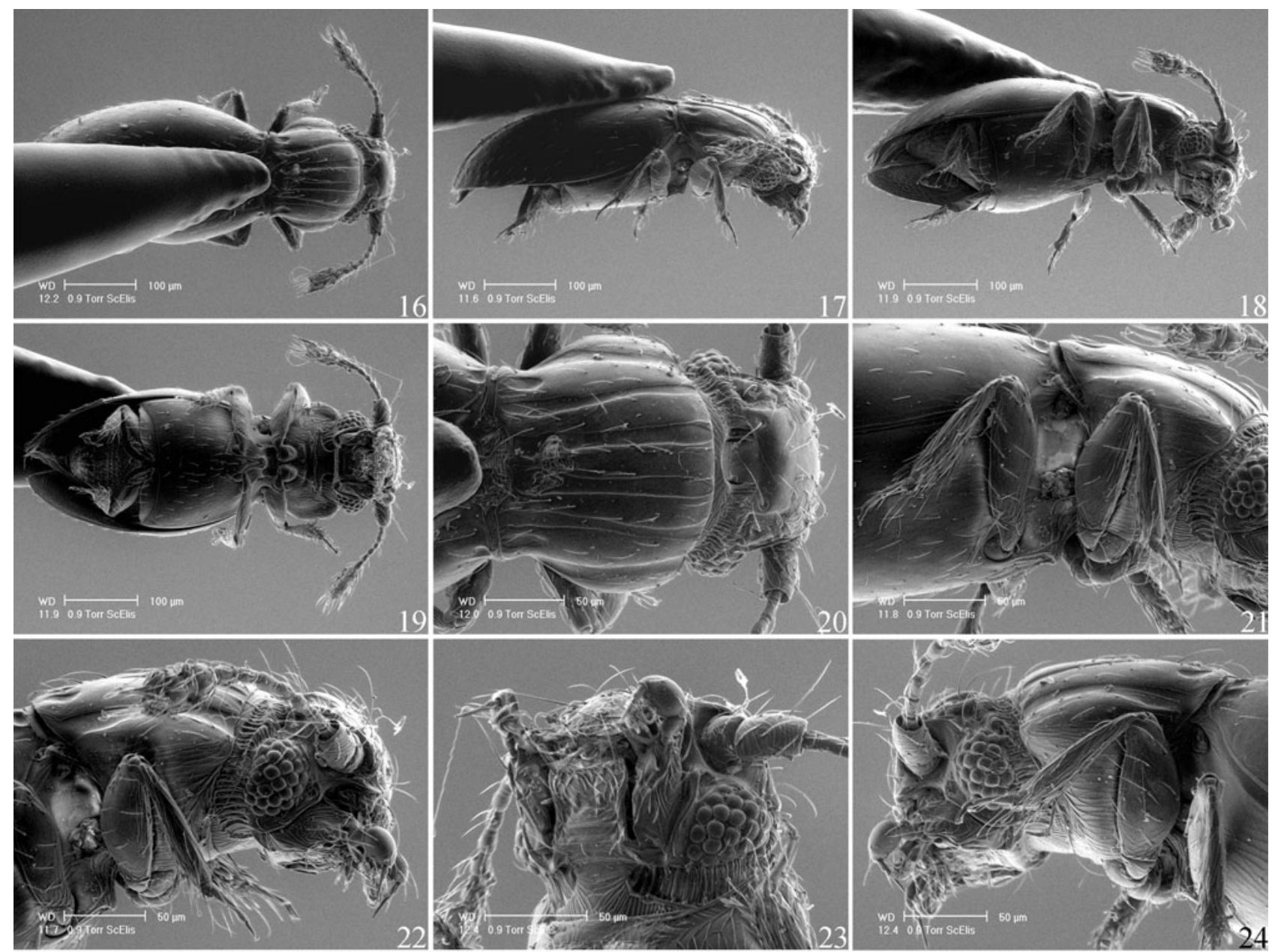

Figs 16-24. Discheramocephalus elisabethae sp. n. from Cameroon (specimen from Buea, Mt. Cameroon), paratype, scanning electron microscopy images. 16 - habitus, dorsal view; 17 - habitus, right lateral view; 18 - habitus, right latero-ventral view; 19 habitus, ventral view; 20 - head and pronotum, dorsal view; 21 - central part of body, right lateral view; 22 - head and pronotum, right lateral view; 23 - head, left ventro-lateral view; 24 - head and pronotum, left latero-ventral view.

\section{Identification key to Discheramocephalus species}

1 Longitudinal furrows on pronotum not exceeding $40 \%$ of pronotal length (Johnson, 2007: Fig. 23) (Solomon Islands) .

............................. semisulcatus

- Longitudinal furrows on pronotum exceed $70 \%$ of pronotal

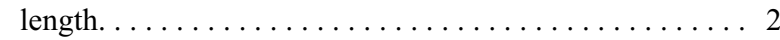

2 Pronotum with two furrows extending $2 / 3$ of pronotal length and flanked on each side by two short basal depressions (Figs 1, 37, 46, 55) .....................

- Pronotum with four furrows extending $2 / 3$ of pronotal length and flanked on each side by one short basal depres-

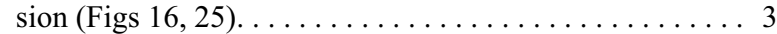

3 Medial longitudinal furrows on pronotum basally as wide as at apex (Fig. 20); distance between ventral arms of postocellar groove larger, about $0.7-0.8 \times$ as wide as width of labium (Fig. 23) (Cameroon)........ D. elisabethae sp. n.

- Medial longitudinal furrows on pronotum basally about 2× wider than at apex (Fig. 30); distance between ventral arms of postocellar groove smaller, about $0.2-0.3 \times$ as wide as width of labium (Fig. 34) (Tanzania). .... . D. mikaeli sp. n.

4 Medial longitudinal furrows on pronotum not exceeding 4/5 of pronotal length (Fig. 59); body less than $0.5 \mathrm{~mm}$ in length (Indonesia)............... minutissimus sp. n.
- Medial longitudinal furrow on pronotum exceeding 9/10 of pronotal length (Figs 4, 40, 50); body more than $0.6 \mathrm{~mm}$ in length. ......................... 5

5 Pygidium distinctly serrate, individual projections subequal in length to tarsal claw (Figs 52, 91); abdominal sternites not transversely serrate (Fig. 52); aedeagus $4-5 \times$ as long as wide (Fig. 93); mesoventer with longitudinal ridges of microsculpture (Fig. 53); metaventral longitudinal lines present (Figs 39, 53) . . . . . . . . . . . . . . . . . 6 Pygidium indistinctly serrate, individual projections 1/2-1/10 the length of tarsal claw (Figs 13-15); abdominal sternites transversely serrate (Fig. 14); aedeagus $8-10 \times$ as long as wide (Figs 96, 97); mesoventer without longitudinal ridges of microsculpture (Fig. 10); metaventral longitudinal lines absent (Fig. 50) (Cameroon). . . . . . D. brucei sp. n.

6 Larger (body length $0.84-0.88 \mathrm{~mm}$ ); two posterolateral basal depressions on pronotum subequal in length (Fig. 40); tarsi 6-7 times as long as wide (Fig. 85) (Bolivia). . . . . . . .......................... D. stewarti sp. n. Smaller (body length $0.65-0.70 \mathrm{~mm}$ ); two posterolateral basal depressions on pronotum differ in length with the outer twice the length of the inner (Fig. 50); tarsi about 15 times as long as wide (Fig. 54) (Bolivia). . D. jarmilae sp. n. 

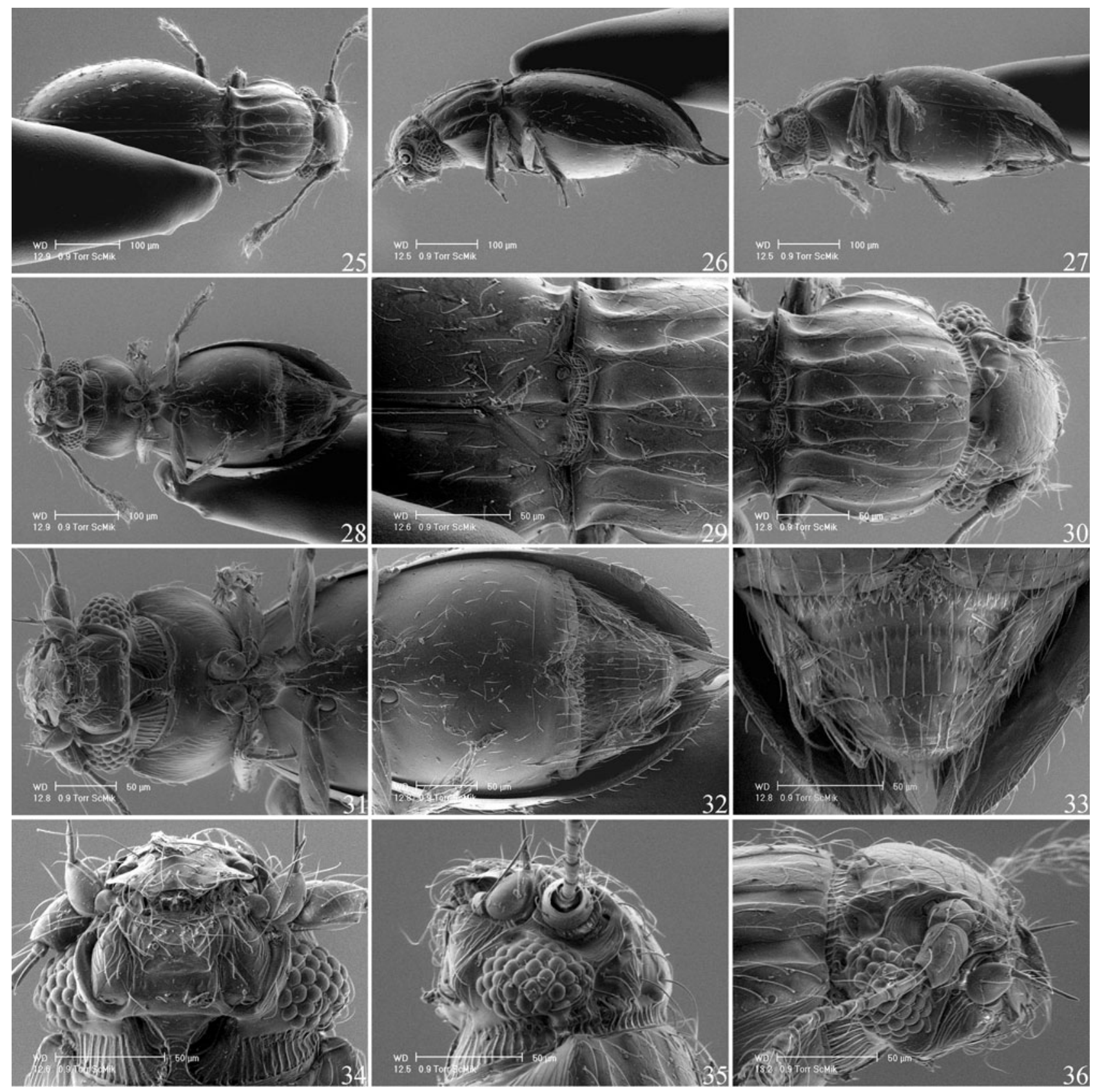

Figs 25-36. Discheramocephalus mikaeli sp. n. from Tanzania, paratype, scanning electron microscopy images. 25 - habitus, dorsal view; 26 - habitus, left lateral view; 27 - habitus, left latero-ventral view; 28 - habitus, ventral view; 29 - base of pronotum, dorsal view; 30 - pronotum, dorsal view; 31 - anterior half of body, ventral view; 32 - posterior half of body, ventral view; 33 abdomen, ventral view; 34 - head, ventral view; 35 - head, left lateral view; 36 - head, right dorso-lateral view.

\section{Discheramocephalus semisulcatus Johnson, 2007}

Johnson, 2007: 224.

Diagnosis. Body length $0.45-0.48 \mathrm{~mm}(\mathrm{n}=4)$; transverse postocellar groove on head apparently closed laterally, bridged by posterior extension of eye joining temple; posterior part of pronotal disk with three short longitudinal furrows on each side adjacent to midline and not longer than $40 \%$ of pronotal length (Johnson, 2007: Fig. 23); each side of abdominal sternite VIII with small cavity about $10 \%$ of sternal width; metaventral longitudinal lines absent; posterior serration on pygidium absent; spermatheca was not described. Male unknown.
Material. No specimens were studied; description is adapted from Johnson (2007). Holotype (female) and three paratypes (females) are deposited in the Natural History Museum, London.

\section{Discheramocephalus brucei sp. $\mathbf{n}$.}

Figs 1-15, 67-69, 93, 99, 101-104.

Diagnosis. Body length $0.61-0.67 \mathrm{~mm}(\mathrm{n}=3)$; transverse postocellar groove on head open laterally, not bridged by posterior extension of eye joining temple; longitudinal grooves on labrum absent; disc of pronotum with one longitudinal furrow on each side adjacent to midline and not shorter than $90 \%$ of pronotal length, 

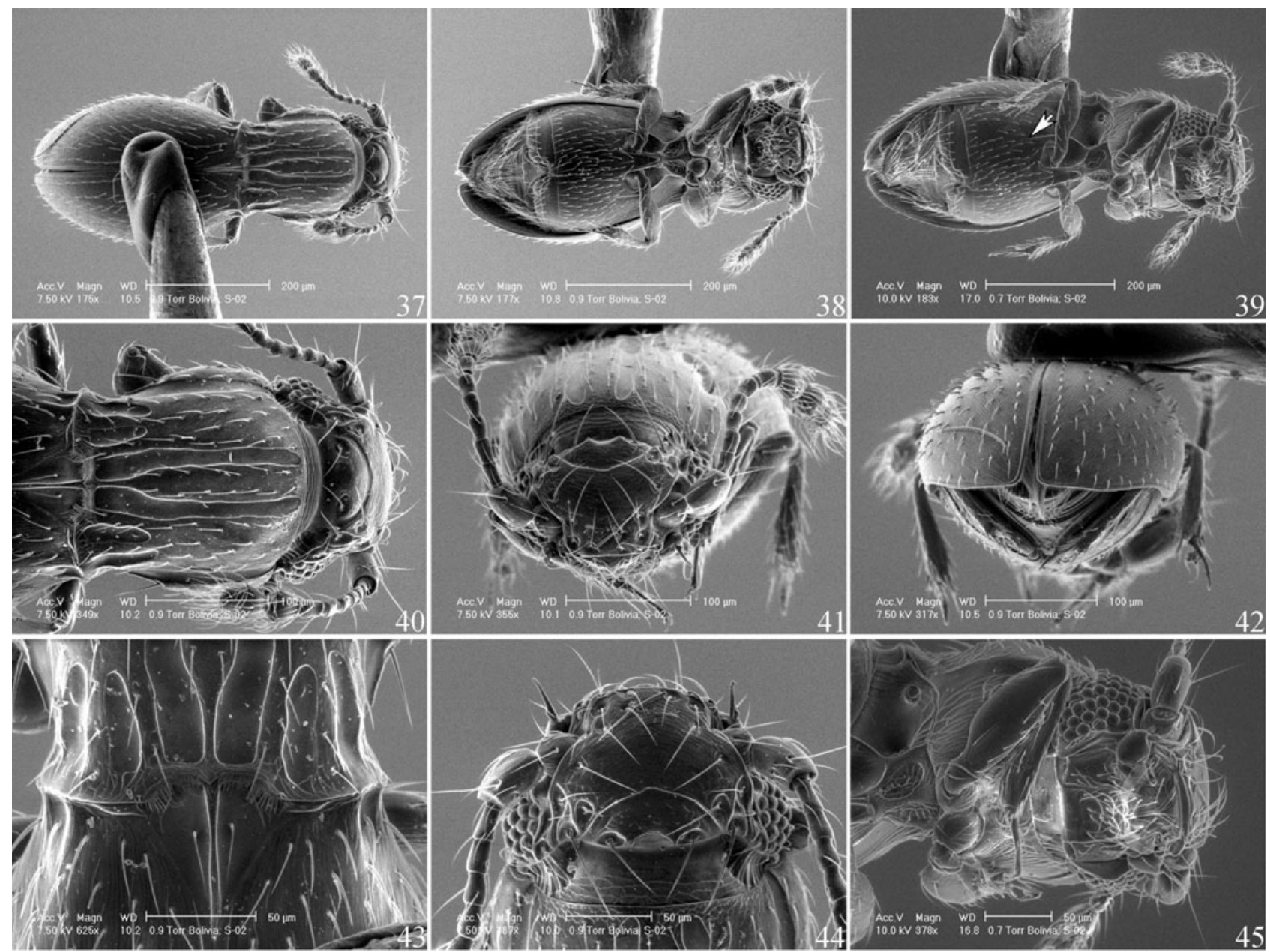

Figs 37-45. Discheramocephalus stewarti sp. n. from Bolivia, paratype, scanning electron microscopy images. 37 - habitus, dorsal view; 38 - habitus, ventral view; 39 - habitus, right ventro-lateral view (arrow indicates metaventral line); 40 - anterior half of body, dorsal view; 41 - anterior half of body, frontal view; 42 - posterior part of body, posterior view; 43 - base of pronotum and elytra, dorsal view; 44 - head, dorsal view; 45 - anterior half of body, right ventro-lateral view.

flanked laterally by two elongate basal depressions; tarsi not broad, about $15 \times$ as long as wide; longitudinal ridges of microsculpture on mesoventer absent or weakly developed; abdominal sternite VIII with transverse row of 5-7 small subequal cavities each not wider than $5 \%$ of sternal width; metaventral longitudinal lines absent; transverse rows of cuticular serration on abdominal sternites present; posterior serration on pygidium absent; aedeagus Fig. 93; spermatheca Fig. 99.

Etymology. Patronymic, the species is named in honour of Dr. Bruce D. Gill, Ottawa, Canada, with whom I undertook fieldwork in Cameroon resulting in the discovery of this new species.

Type material. Holotype ( $(+)$ mounted in Euparal on a microscope slide: Cameroon, N.-West province, Mt. Oku, N06 ${ }^{\circ} 13.294^{\prime}$ E010 $30.221^{\prime}$, 4.-5.v.2006, 2,800 m, V. Grebennikov. Paratypes: 15 specimens. Seven with the same data as holotype; four of them are in vials of $70 \%$ ethanol and three others are mounted in Euparal on three microscope slides. Eight other specimens: Cameroon, N.-West province, Mt. and Lake

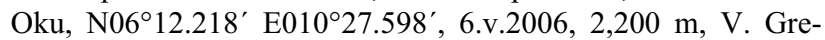
bennikov; six of them in $70 \%$ ethanol and two others are mounted together in Euparal on one microscope slide. Two more specimens from the same locality (Mt. and Lake Oku) were sectioned on a microtome for histological studies and not designated as paratypes.

Remarks. A single specimen of a Discheramocephalus species closely resembling, or possibly conspecific with, D. brucei was collected in the Korup National Park, Cameroon (Fig. 70). It differs from D. brucei, however, in shorter body, differently shaped abdomen (in dorsal view), and pronotum having obtuse angulation at the middle of lateral edges (Fig. 70). Whereas all other African Discheramocephalus species were sifted out of leaf litter in the mountain forests at altitudes above 1,000 meters, this single specimen was taken by a flight intercept trap in the lowland forest at 300 meters above sea level. This is the only record of Discheramocephalus from the Korup National Park, although extensive sifting of the leaf litter was undertaken there. Additional material is needed to clarify the identity of this population. The specimen is stored in $75 \%$ ethanol and bears the following label data: "Cameroon: S.-West province, Korup N.P., Rengo Camp, N0502.194' E00849.769’, 12.-16.v.2006, 300 m, V. Grebennikov leg”. 

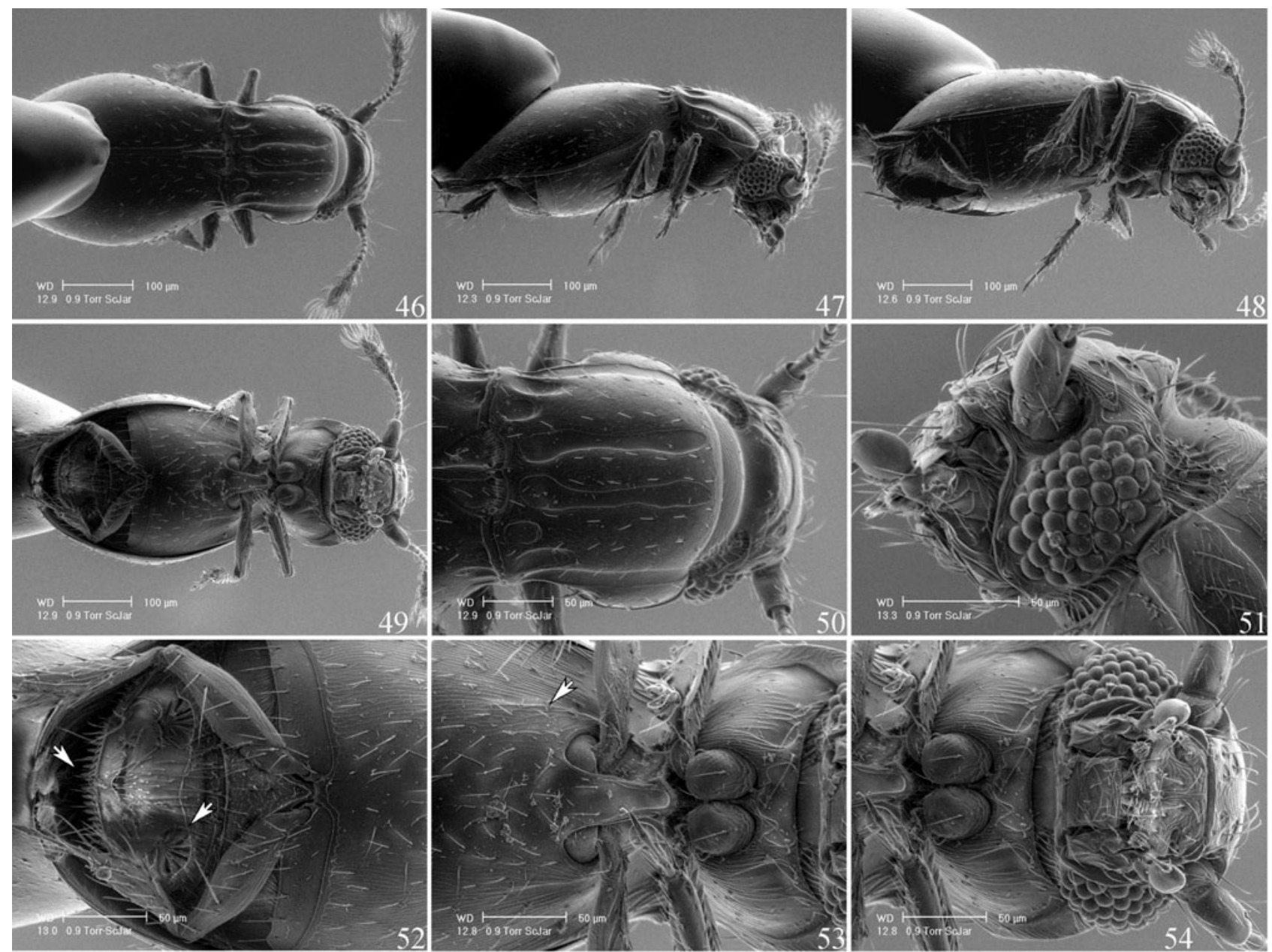

Figs 46-54. Discheramocephalus jarmilae sp. n. from Bolivia, paratype, scanning electron microscopy images. 46 - habitus, dorsal view; 47 - habitus, right lateral view; 48 - habitus, right latero-ventral view; 49 - habitus, ventral view; 50 - head and pronotum, dorsal view; 51 - head, left lateral view; 52 - posterior half of body, ventral view (left arrow indicates serration on pygidium, right arrow indicates one of two large cavities on abdominal sternite VIII); 53 - central part of body, ventral view (arrow indicates metaventral line); 54 - anterior half of body, ventral view.

\section{Discheramocephalus elisabethae sp. $\mathbf{n}$.}

Figs 16-24, 71-74, 94.

Diagnosis. Body length $0.51-0.56 \mathrm{~mm}(\mathrm{n}=2)$; transverse postocellar groove on head open laterally, not bridged by posterior extension of eye joining temple; longitudinal grooves on labrum absent; disc of pronotum with two longitudinal furrows on each side adjacent to midline and not shorter than $90 \%$ of pronotal length, flanked laterally by one elongate basal depression; tarsi not broad, about $15 \times$ as long as wide; longitudinal ridges of microsculpture on mesoventer absent or weakly developed; abdominal sternite VIII with transverse row of 5-7 small subequal cavities each not wider than $5 \%$ of sternal width; metaventral longitudinal lines absent; transverse rows of cuticular serration on abdominal sternites present; posterior serration on pygidium absent; aedeagus Fig. 94; spermatheca as in Fig. 99.

Type material. Holotype ( $($ ) mounted in Euparal on a microscope slide: Cameroon: S.-West province, Buea, N0409.787'; E009¹3.408', 9.v.2006, 1,200 m, V. Grebennikov. Paratypes: Eight specimens. Four with the same data as holotype; three of them in $70 \%$ ethanol (one used for SEM in a separate vial) and one is mounted in Euparal on a microscope slide. Four other specimens: Cameroon, S.-West province, Mt. Kupe at Nyasoso, N0449.153' E00942.453', 19.-21.v.2006, $1,550 \mathrm{~m}, \mathrm{~V}$. Grebennikov; two of them in $70 \%$ ethanol and two others are mounted in Euparal on two microscope slides.

Etymology. Patronymic, the species is named in honour of Frau Elisabeth Hintelmann, Munich, Germany. Frau Hintelmann has established a scientific foundation at the Zoologische Staatssammlung München in memory of her late husband Robert J.H. Hintelmann. This foundation funded my fieldwork in Cameroon, which resulted in the discovery of this species.

Remarks. Aedeagi of $D$. elisabethae males are remarkably long and amount to about $1 / 3(32 \%)$ of the body length (Fig. 75). This relative length might be among the largest in Coleoptera.

\section{Discheramocephalus mikaeli sp. $\mathbf{n}$.}

Figs 25-36, 77, 78, 95.

Diagnosis. Body length $0.56-0.60 \mathrm{~mm}(\mathrm{n}=3)$; transverse postocellar groove on head open laterally, not bridged by posterior extension of eye joining temple; two longitudinal grooves on labrum present, apically separated; disc of pronotum with two longitudinal furrows on 

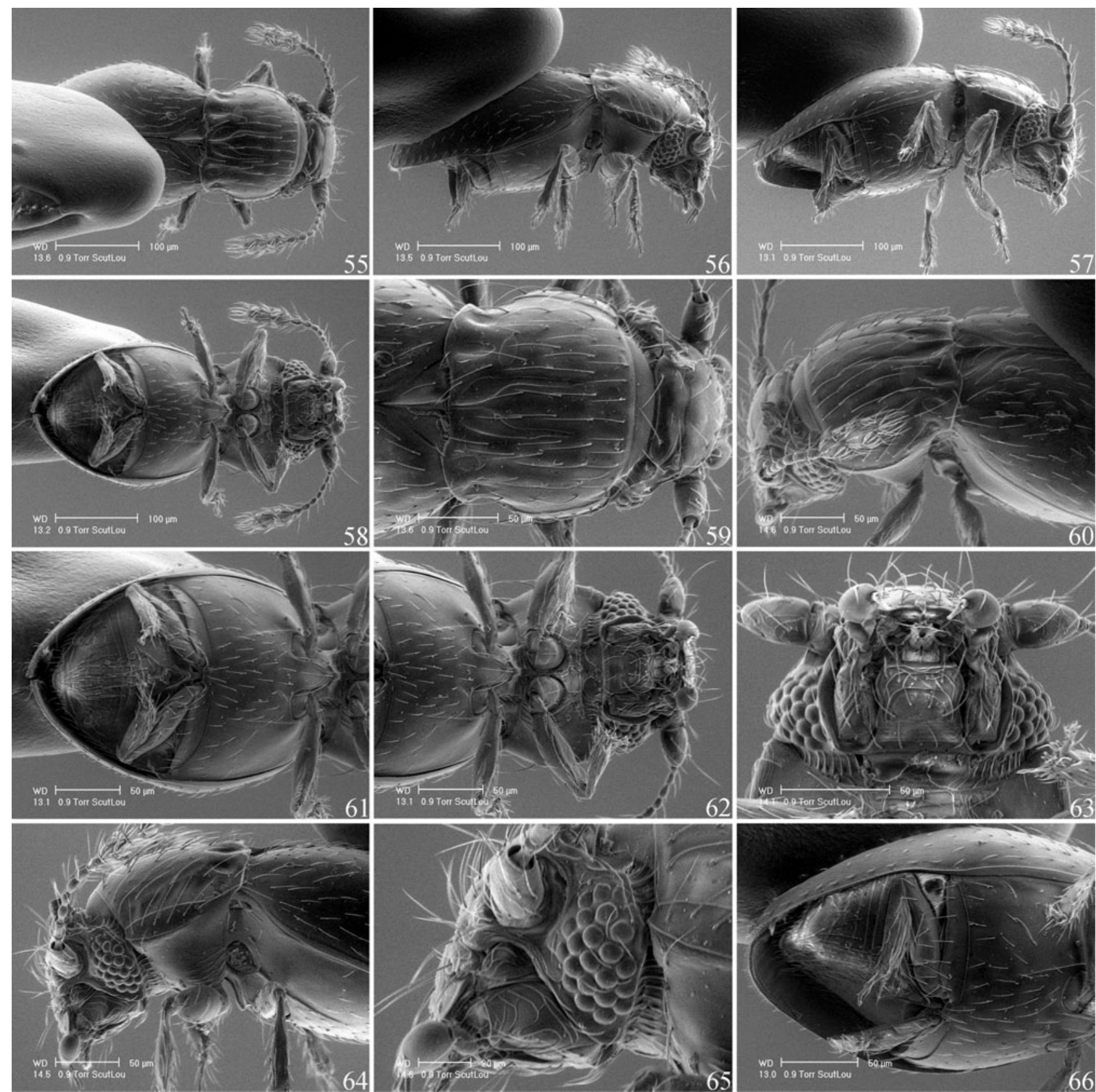

Figs 55-66. Discheramocephalus minutissimus sp. n. from Indonesia, holotype, scanning electron microscopy images. 55 - habitus, dorsal view; 56 - habitus, right lateral view; 57 - habitus, right latero-ventral view; 58 - habitus, ventral view; 59 - head and pronotum, dorsal view; 60 - anterior half of body, left dorso-lateral view; 61 - posterior half of body, ventral view; 62 - anterior half of body, ventral view; 63 - head, ventral view; 64 - anterior half of body, left lateral view; 65 - head, left lateral view; 66 - posterior half of body, right latero-ventral view.

each side adjacent to midline and not shorter than $90 \%$ of pronotal length, flanked laterally by one longitudinal basal depression; tarsi not broad, about $15 \times$ as long as wide; longitudinal ridges of microsculpture on mesoventer absent or weakly developed; abdominal sternite VIII with transverse row of 5-7 small cavities each not wider than $5 \%$ of sternal width, two most lateral of them about twice width of medial ones; metaventral longitudinal lines absent; transverse rows of cuticular serration on abdominal sternites present; posterior serration on pygidium absent; aedeagus Fig. 95; spermatheca as in Fig. 99.
Type material. Holotype ( $($ ) mounted in Euparal on a microscope slide (together with another conspecific male specimen, a paratype): Tanzania, W. Usambara Mts, Lushoto district, Grant's Lodge, Mkuzu river, 3-4 km upstream of the village of Kifungilo, 3.-8.x.2002, 1,660 m, V. Grebennikov. Paratypes: 14 specimens with the same data as holotype; seven of them in $70 \%$ ethanol (one used for SEM in a separate vial) and other seven are mounted in Euparal on four microscope slides (one of them containing the holotype; see above).

Etymology. Patronymic, the species is named in honour of Mr. Mikael Sörensson, Lund, Sweden, who introduced me to ptiliid beetles. 


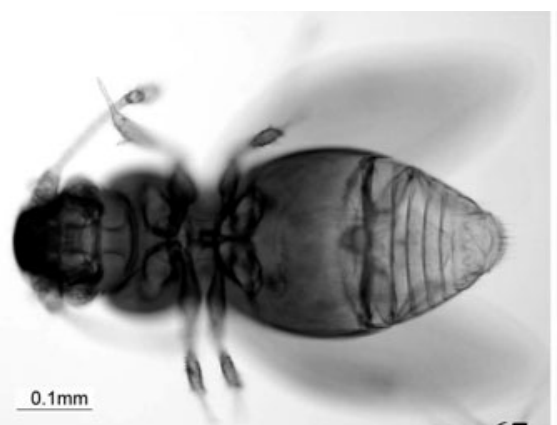

67

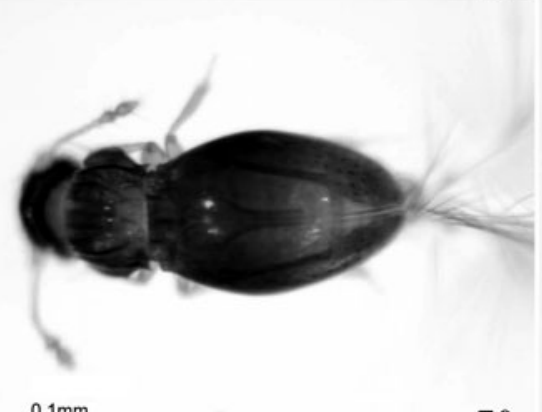

$0.1 \mathrm{~mm}$

70
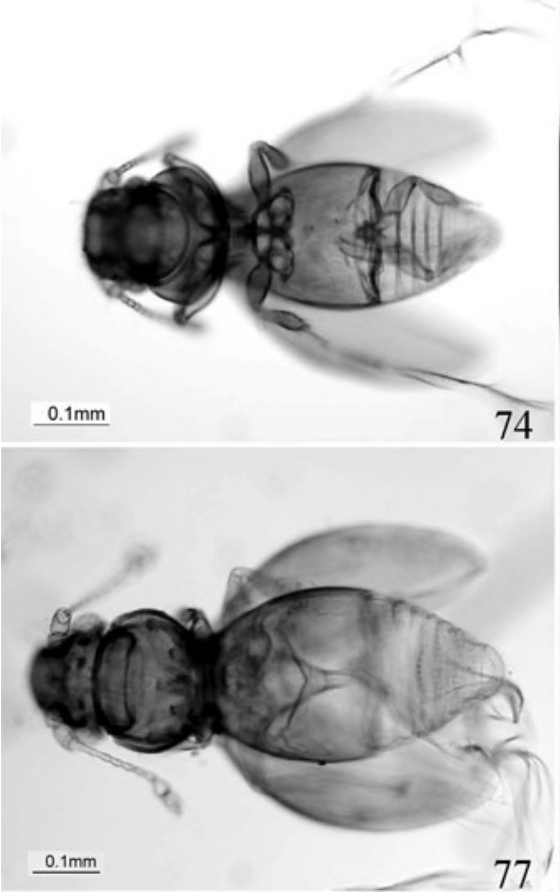

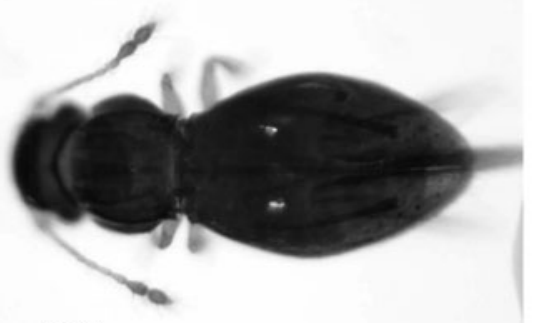
$\underline{0.1 \mathrm{~mm}}$

68

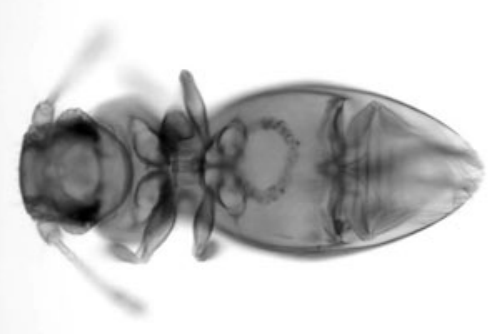

71
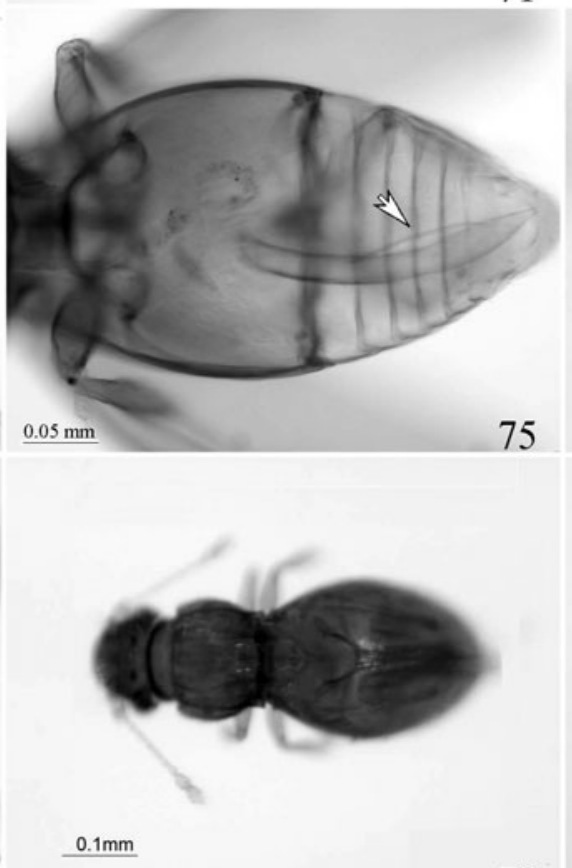

78
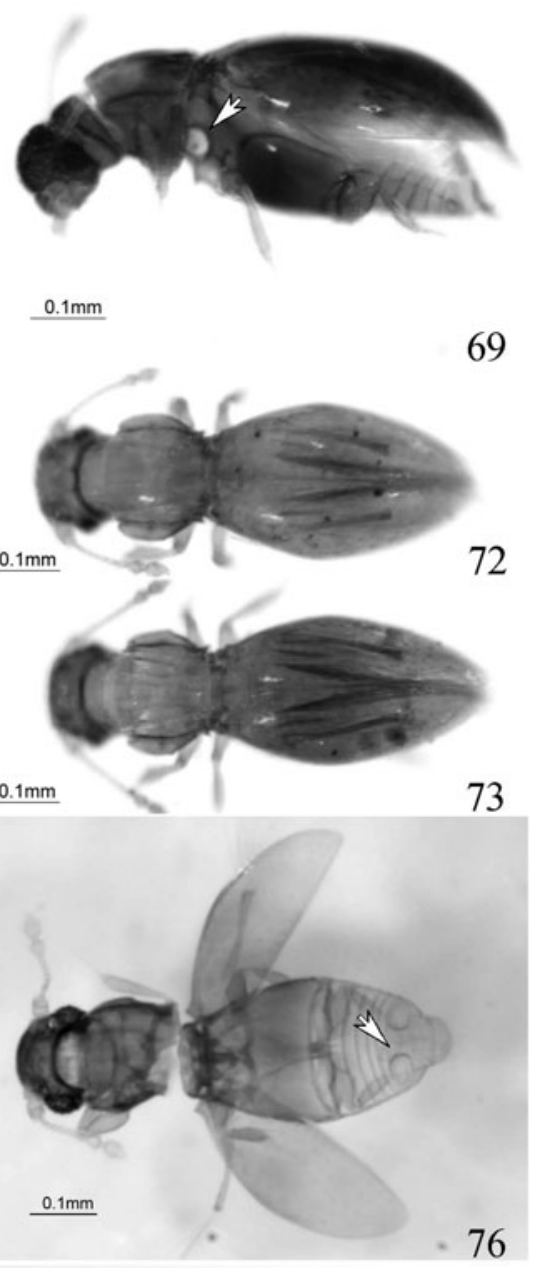

69

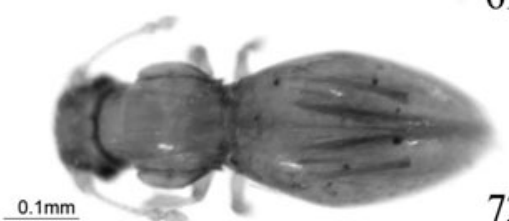

72

$0.1 \mathrm{~mm}$

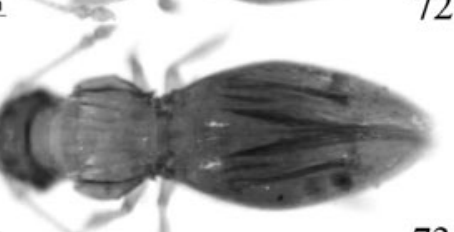

73

Figs 67-79. Discheramocephalus spp., light microscopy images. $67-$ D. brucei, holotype, habitus, ventral view; $68-D$. brucei, habitus, dorsal view; 69 - D. brucei, habitus, left lateral view (arrow indicates transverse fossa on mesoventral keel); 70 - Discheramocephalus sp. from Korup National park, Cameroon, habitus, dorsal view; $71-$ D. elisabethae, holotype, habitus, ventral view; 72 - D. elisabethae from Buea, Cameroon (type locality), habitus, dorsal view; 73 - S. elisabethae from Mt. Kupe, Cameroon, habitus, dorsal view; $74-$ D. elisabethae, male, habitus, ventral view; 75 - same as in Fig. 74, enlarged view at abdomen with arrow showing aedeagus and associated elongated internal sclerite, ventral view; $76-D$. jarmilae from Bolivia holotype, habitus, dorsal view (arrow indicates one of two large cavities on abdominal sternite VIII); $77-D$. mikaeli, holotype, habitus, dorsal view; $78-D$. mikaeli, habitus, dorsal view; $79-$ D. minutissimus, habitus, ventral view. Scale bar: $0.1 \mathrm{~mm}$.

\section{Discheramocephalus stewarti sp. n.}

Figs 37-45, 80-92, 98, 100.

Diagnosis. Body length $0.84-0.88 \mathrm{~mm}(\mathrm{n}=2)$; transverse postocellar groove on head closed laterally and fully bridged by posterior extension of eye joining temple; longitudinal grooves on labrum absent; disc of pronotum with one longitudinal furrow on each side adjacent to midline and not shorter than $90 \%$ of pronotal length, flanked laterally by two longitudinal basal depressions; tarsi broad, about $6-7 \times$ as long as wide; longitudinal ridges of microsculpture present on mesoventer; abdominal sternite VIII on each side with one large cavity 

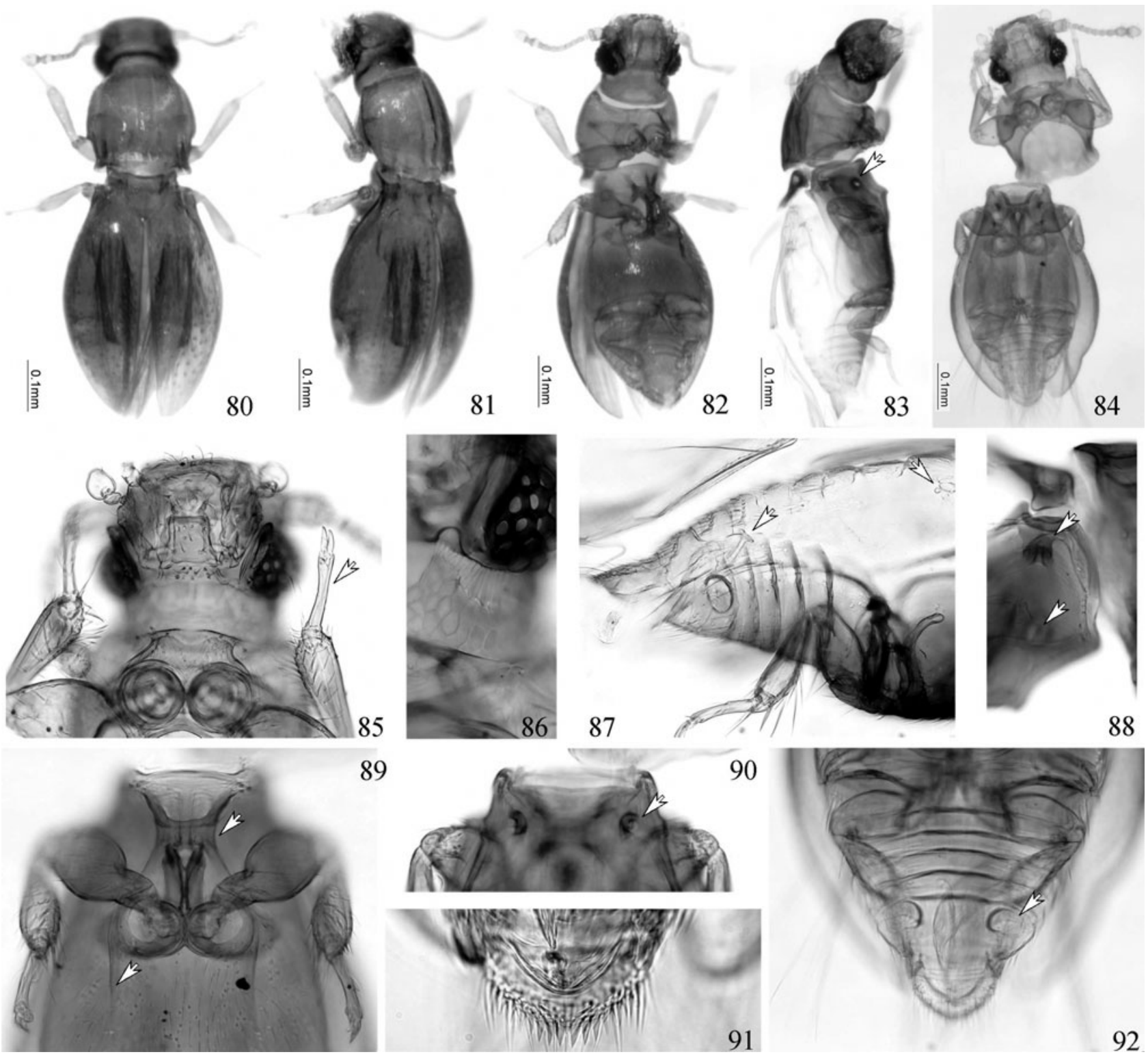

Figs 80-92. Discheramocephalus stewarti sp. n., light microscopy images. 80 - habitus, dorsal view; 81 - habitus, left dorsolateral view; 82 - habitus, right ventro-lateral view; 83 - habitus, right elytron removed, right lateral view (arrow indicates transverse fossa on mesoventral keel); 84 - holotype, habitus, ventral view; 85 - head and prothorax, ventral view (arrow indicates markedly broader tarsus); 86 - left eye and postocellar groove, ventral view; 87 - abdomen, right elytron removed, right lateral view (arrow indicates pump of spermatheca); 88 - mesothorax showing mesoventral keel, right elytron removed, right lateral view (upper arrow indicates vertical fossa in anterior corner of mesoventer, lower arrow indicates horizontal fossa in mesoventral keel, which is out of focus); 89 - meso- and metaventer, ventral view (upper arrow points to lateral openings of horizontal fossa in mesoventral keel, lower arrow indicates mesoventral lines); 90 - mesoventer, ventral view (arrow indicates openings of vertical fossa in anterior corner of mesoventer); 91 - serrate apex of pygidium, ventral view; 92 - hind legs and abdomen, ventral view (arrow indicates one of two large cavities on abdominal sternite VIII). Scale bars for Figs 85-92 are not indicated; dimensions of these structures can be estimated by referring to Figs $80-84$ of the complete adult body.

of about $20 \%$ of sternal width; metaventral longitudinal lines present, extending posteriorly for about $1 / 3$ of metaventral length; transverse rows of cuticular serration on abdominal sternites absent; posterior serration on pygidium consisting of about 25 individual cuticular projections subequal in size to tarsal claw; aedeagus Fig. 96; spermatheca Fig. 99.

Etymology. Patronymic, the species is named in honour of Prof. Stewart B. Peck, Ottawa, Canada, who, along with his wife Jarmila Kukalová-Peck, collected this new species in Bolivia.

Type material. Holotype ( $₫$ ) mounted in Euparal on a microscope slide and oriented dorso-ventrally: Bolivia, Cochabamba Department, Villa Tunari, Hotel El Puente, S16 $59.02^{\prime}$ $\mathrm{W}_{65^{\circ}} 24.50^{\prime}, 357 \mathrm{~m}, 15 .-27 . x i i .2005$, rainforest FIT, \#05-45, S. \& J. Peck. Paratypes: Two specimens with the same data as holotype; one in $70 \%$ ethanol and another ( $\%$ ) mounted on the same microscope slide as the holotype, and oriented laterally. 


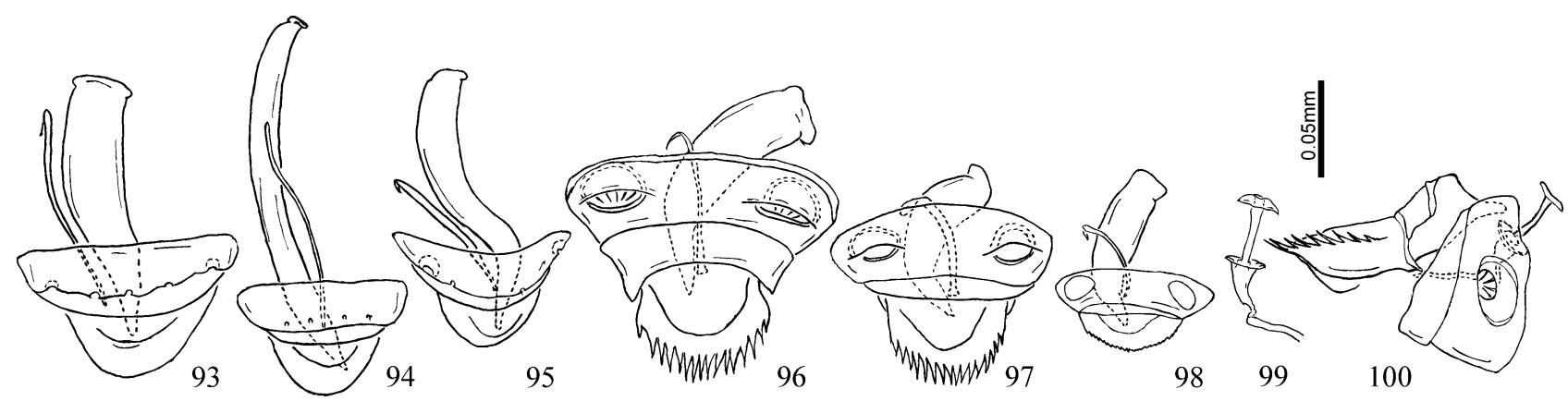

Figs 93-100. Discheramocephalus spp., ventral (93-99) and right lateral (100) views; male genitalia and abdominal sternites VIII and IX (93-98), spermatheca (99), abdominal tergites XI, X and sternites VIII and IX (100). 93, 99 - Discheramocephalus brucei; 94 - D. elisabethae; 95 - D. mikaeli; 96, 100 - D. stewarti; 97 - D. jarmilae; 99 - D. minutissimus.

\section{Discheramocephalus jarmilae sp. $\mathbf{n}$.}

Figs 46-54, 76, 97.

Diagnosis. Body length $0.64-0.70 \mathrm{~mm}(\mathrm{n}=3)$; transverse postocellar groove on head closed laterally and fully bridged by posterior extension of eye joining temple; longitudinal grooves on labrum absent; disc of pronotum with one longitudinal furrow on each side adjacent to midline and not shorter than $90 \%$ of pronotal length, flanked laterally by two longitudinal basal depressions; tarsi not broad, about $15 \times$ as long as wide; longitudinal ridges of microsculpture present on mesoventer; abdominal sternite VIII on each side with one large cavity of some $20 \%$ of sternal width; metaventral longitudinal lines present, extending posteriorly for about $1 / 3$ of metaventral length; transverse rows of cuticular serration on abdominal sternites absent; posterior serration on pygidium consisting of about 25 individual cuticular projections subequal in size to tarsal claw; aedeagus Fig. 97; spermatheca as in Fig. 99.

Etymology. Patronymic, the species is named in honour of Dr. Jarmila Kukalová-Peck, Ottawa, Canada, who, along with her husband Stewart B. Peck, collected this new species in Bolivia.

Type material. Holotype ( $\delta$ ) mounted in Euparal on a microscope slide: Bolivia, Cochabamba Department, Villa Tunari, Hotel El Puente, S16 59.02' W6524.50', 357 m, 15.-27.xii.2005, rainforest FIT, \#05-45, S. \& J. Peck. Paratypes: Eight specimens with the same data as holotype; two in separate vials with $70 \%$ ethanol (one of them has been used for SEM images) and six more mounted on five Euparal microscope slides.

\section{Discheramocephalus minutissimus sp. $\mathbf{n}$.}

Figs 55-66, 79, 98.

Diagnosis. Body length $0.40-0.43 \mathrm{~mm}(\mathrm{n}=3)$; transverse postocellar groove on head open laterally, not bridged by posterior extension of eye joining temple; two longitudinal grooves on labrum present, apically joined; disc of pronotum with one longitudinal furrow on each side adjacent to midline and not longer than $80 \%$ of pronotal length, flanked laterally by two elongate basal depressions; tarsi not broad, about $15 \times$ as long as wide; longitudinal ridges of microsculpture on mesoventer absent or weakly developed; abdominal sternite VIII on each side with one large cavity of about $20 \%$ of sternal width; metaventral longitudinal lines present, extending posteriorly for about half of metaventral length; transverse rows of cuticular serration on abdominal sternites absent; posterior serration on pygidium consisting of about 20 individual cuticular projections much smaller than tarsal claw; aedeagus Fig. 98; spermatheca as in Fig. 99.

Etymology. The specific epithet is the Latin adjective minutus, - $a$, -um (little, small, minute) in superlative form and refers to the minute body size of this species.

Type material. Holotype (sex unknown; deposited in Muséum National d'Histoire Naturelle, Paris, France, MNHN) dry mounted on the point of an entomological pin and used for SEM: Indonesia, Sumatera Barat, Maninjau, Kotomalintang, Kebun durian, litter, berlese, 12.vii.1992, 750 m., L. Deharveng $\&$ A. Bedos. Paratypes: three, with the same data as holotype; one of them in $70 \%$ ethanol $(\mathrm{CNCI})$ and other two mounted in Euparal on two microscope slides (one in CNCI, one in MNHN).

\section{DISCUSSION ON INSECT MINIATURIZATION}

It is difficult to propose a universally applicable measurement for determining the absolute size of animals. For practical purposes, body length is often used, measured along the longest axis of a specimen's body and excluding appendages or other body extensions, like the ovipositor, which do not significantly contribute to body volume. Body size has the major advantage of being relatively easy to measure and to compare. Still, there are some assumptions and approximations routinely used when dealing with this parameter. Body volume (or weight) might be the single best parameter to compare, although it is subject to extreme modifications even within a single organism depending on how dehydrated, starved, etc. it is. Thus, body length is normally the most convenient measurement to use when deciding which is smaller or larger. Immature stages are generally smaller in size than adults and, therefore, it is customary to use the maximum body length of a fully grown and sexually mature specimen. Even this simplified measurement poses considerable difficulties, because animals with telescopic or jointed body parts are subject to shrinking or bending, which affects the accuracy of measurement.

The widely cited body length of $260 \mu \mathrm{m}$ for the smallest beetle (Crowson, 1981) is a measurement error 

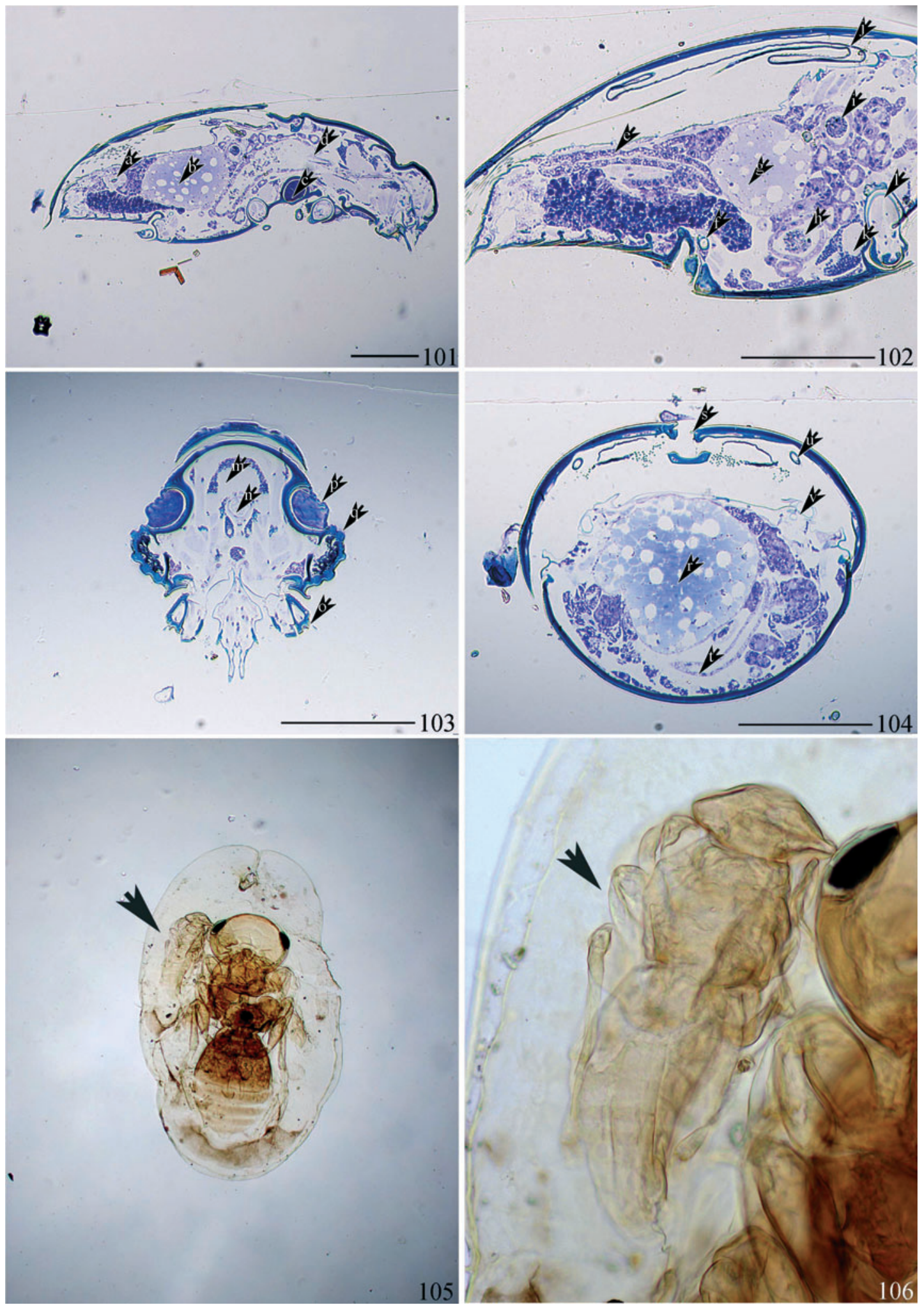

Figs 101-106. Extreme examples of insect miniaturization in Coleoptera and Hymenoptera. 101-104: Adult histological sections of Discheramocephalus brucei (Coleoptera: Ptiliidae). 101 - longitudinal section through the whole beetle; $a$ - spermatheca; $b$ maturing egg; $\mathrm{c}$ - horizontally oriented fossa through mesoventral keel; $\mathrm{d}$ - foregut merging with midgut. 102 - longitudinal section through posterior part of thorax and abdomen; $\mathrm{e}$ - Malpighian tube; $\mathrm{f}$ - metendosternite; $\mathrm{g}$ - maturing egg; $\mathrm{h}, \mathrm{i}$ - coil of midgut; $\mathrm{j}$ wing; $\mathrm{k}$ - metathoracic ganglion; 1 - mesocoxa. 103 - cross section through the head; $\mathrm{m}$ - brain (cephalic ganglion); $\mathrm{n}-\mathrm{foregut}$; $\mathrm{o}-$ stipes; $p$ - transverse external groove on head; $q$ - eye. 104 - cross section through thorax and abdomen between meso- and metacoxae; $\mathrm{r}$ - maturing egg; $\mathrm{s}$ - elytral interlocking device; $\mathrm{t}$ - coil of midgut; $\mathrm{u}$ - basal part of wing; $\mathrm{v}$ - spiracle. Scale bars: $100 \mu \mathrm{m}$. 105-106: Dwarf and likely blind male with body length $280 \mu \mathrm{m}$ (left, indicated by arrow) and fully developed much larger female (right) of Errolium sp. (Hymenoptera: Platygastridae) inside host egg (likely Inglisia sp., Coccidae; see Masner \& Huggert, 1989) under low (105) and high (106) magnification. Note that the larger female does not have fully developed wings, which expand later after emergence from the host egg. 
recently corrected by Sörensson (1997). This author gave the real minimal body length for beetles as about $400 \mu \mathrm{m}$, although later Hall (1999) cited 300-350 $\mu \mathrm{m}$ for some of his new species of Nanosellini (Ptiliidae). The newly described Discheramocephalus minutissimus further suggests that $350-400 \mu \mathrm{m}$ might be close to the true lower limit of body length in Coleoptera.

There is no evidence that extreme miniaturization of adult and larval body size of featherwing beetles is achieved through significant morphological reduction and structural simplification, as exemplified in some hymenopteran egg-parasitoids (Mockford, 1997) and suggested as a general trend for all minute animals (Hanken \& Wake, 1993). Discheramocephalus species described herein do not demonstrate significant internal or external simplification compared to medium-sized beetles. There is only some reduction, such as the presence of only one ovary (Polilov, 2005) and complete lack of a heart (Fig. 104). Minute larvae of Ptiliidae are known to possess the normal chaetotaxy and musculature of the head despite their extremely small size (Grebennikov \& Beutel, 2002).

Discheramocephalus minutissimus, along with some other minute species of featherwing beetles, has a body length of about $400-420 \mu \mathrm{m}$ and, therefore, is among the smallest winged insects. Besides Ptiliidae, only a few groups of hymenopteran egg-parasitoids, accounting for less than $1 \%$ of insect species diversity, are known to reach, and even to exceed, this size threshold, and are the smallest insects known. No species from groups of winged insects other than Ptiliidae and egg-parasitic Hymenoptera is reliably known to be as small as 350-400 $\mu \mathrm{m}$ in body length in the adult stage.

Two facts related to the process of insect body miniaturization are of general biological interest. One is that the size of about $400 \mu \mathrm{m}$ seems to be the lower limit of body length for free-living insects, as exemplified by featherwing beetles. This suggests that there is a lower limit to further miniaturization. Another fact is that hymenopteran egg-parasitoids are able to overcome this threshold and become significantly smaller. Either eggparasitoids might bypass the limit to miniaturization in non-egg-parasitoid insects or, alternatively, this main limitation acts differently in egg-parasitoids compared to other insects.

Polilov $(2005,2007)$ hypothesized that the main constraint for the process of body miniaturization in adult insects is the limit imposed by the necessity to produce eggs large enough to permit development of a viable larva. Three implications result from this hypothesis.

Implication 1: Selective pressure on minute organisms will be directed towards supporting females laying fewer eggs per time unit, which ultimately results in only one egg maturing in a female at one time. A by-product of this implication is that only a single ovary per female might be expected to exist in the smallest organisms. This is indeed true in Ptiliidae and in many other insect (and noninsect) groups with extremely small species, like eriophyoid mites (Nuzzaci \& Alberti, 1996).
Implication 2: Due to their unique biology hymenopteran egg-parasitoids might be exceptionally capable of miniaturization. The reason is that eggs of egg-parasitoids are laid directly into eggs of host species and, therefore, their newly hatched larvae have a unique opportunity to utilize the stored resources of the host egg. Thus, the egg of an egg-parasitoid can afford to be markedly less supported with resources than an egg of any other insect. This permits the egg-parasitoid female to achieve a smaller size compared to insects with free-living larvae. Many other insects have larvae that develop inside a plant or animal host and thus are surrounded by an abundance of food; however, none of them are able to match eggparasitoids in body miniaturization. The reasons for this may be that the egg is particularly rich in resources easily metabolized by the newly hatched parasitoid larva compared to the tissues of hosts in later developmental stages. Another explanation is a purely physical constraint: the maximum body size of an egg-parasitoid adult is determined by the size of the host egg, e.g. very small eggs of Psocoptera or Thysanoptera can only yield a very small adult parasitoid (Doutt \& Viggiani, 1968).

The phenomenon of egg-parasitoids completing their development in a host egg is known in Insecta only in four families of Hymenoptera: Mymaridae and Trichogrammatidae of Chalcidoidea (Grissell \& Schauff, 1997), and Scelionidae and Platygastridae: Sceliotrachelinae of Platygastroidea (Pennacchio \& Strand, 2006). Species of these groups, particularly of both chalcidoid families, include the smallest known female insects: $186 \mu \mathrm{m}$ in body length (Dozier, 1932; Doutt \& Viggiani, 1968; Mockford, 1997).

Implication 3: The hypothesis of a limit to female miniaturization leaves males not accounted for. This suggests that males could have a greater ability to become smaller then females. The reason is that the female has to produce an egg, whereas the male has to produce only fertile sperm, which does not normally require as much resources as an egg. This is in line with Rensche's rule that females of smaller animals tend to be larger than males, whereas in larger animals the opposite is true, as convincingly illustrated for flower mites and humming birds (Colwell, 2000); two groups holding records of body miniaturization in Acarina and Aves, respectively.

The most convincing illustration that egg size limits female insect body miniaturization is the smallest known insect, Dicopomorpha echmepterygis Mockford, 1997, a mymarid egg-parasitoid (Mockford, 1997). Females of this species are $386-550 \mu \mathrm{m}$ in body length, winged, fully functional, and are known to produce a single egg at a time, 106-110 $\mu \mathrm{m}$ in length. Males, however, are minute, blind, wingless and 139-240 $\mu \mathrm{m}$ in length, which is the record for small body length in the Insecta (Mockford, 1997). It should be noted that having half the body length of the female, the body volume of males is an eighth of that of females.

This phenomenon of dwarf and structurally simplified males is relatively widespread in minute Hymenoptera. In Trichogrammatidae, Prestwichia aquatica Lubbock, 1863 
has apterous males (Enock, 1896), which copulate with females inside the host egg (Enock, 1898), while its freshly hatched larva is a minute non-segmented creature lacking all major tissue systems but for a few muscles used to feed on a host egg of Dytiscidae (Coleoptera) (Ivanova-Kazas, 1950, 1962). Masner \& Huggert (1989) cited E. Valentine's observation that a dwarf, apterous and blind male was observed inside the same host egg skin as was a female of an undescribed Errolium species (Platygastridae) in New Zealand (present Figs 105-106). Unlike the degenerate blind and apterous males of D. echmepterygis (Mymaridae), Errolium males are known in both degenerate and fully developed form (E. Valentine in Masner \& Huggert, 1989). Similar blind, apterous and morphologically simplified (although not dwarfed) males can be found in Melittobia Westwood, 1847 (Hymenoptera: Chalcidoidea: Eulophidae), gregarious parasites of Aculeata prepupae (Dahms, 1984). Adults of this genus are not extremely small, ranging between 1.0 and $1.5 \mathrm{~mm}$ in length. This example demonstrates the existence of other factors, besides miniaturization, which might lead to morphological simplification of males in parasitic Hymenoptera.

Polilov $(2005,2007)$ hypothesized that brain size might be the second most important factor limiting insect miniaturization. Neuron cell body size reaches a lower limit of $2 \mu \mathrm{m}$ in diameter in the smallest insects, which is at the lowest recorded limit in multicellular animals (Beutel et al., 2005; Polilov, 2005). The smallest brains still have to maintain all circuits of sensory input necessary for the organism to function (Kaas, 2000). This is particularly true for the adult stage compared to larvae, because adults may need a larger brain to handle more complex behaviour and associated necessary sensory input. Another restricting mechanism might be the necessity to maintain a certain proportion between neuron body size and axon diameter. The latter have to be greater than $0.1 \mu \mathrm{m}$ in diameter to permit transmission of a signal (Faisal et al., 2005). The third limiting mechanism might be genome size, which limits volume of the nucleus by filling it up with chromatin. The nucleus occupies $80-90 \%$ of a neuron cell body in Ptiliidae (Polilov, 2005), thus genome size, brain size and linear body size are possibly linked together as correlated parameters.

Any object moving through air is subject to the laws of fluid mechanics. The hypothesis of Horridge (1956) that small insects "have abandoned altogether the aerofoil action and that they literally 'swim' in the air" is currently not supported (Ellington, 1999). As insects become smaller, the viscosity of the air increases proportionally, which leads to a higher energy cost for active flight. This physical phenomenon might be another factor partly limiting insect miniaturization. Existence of this flightimposed constraint is partly suggested by the fact that smallest flying insects like Ptiliidae or Mymaridae have a similar, light-weight wing structure with the wing membrane markedly reduced in width and substituted by a fringe of trichia, which increase flapping surface and lift. Wing weight reduction is likely an aspect of a small arthropod's structural need to reduce weight of articulated appendages and associated muscles.

Some non-flying arthropods are markedly smaller then the smallest Pterygota. Eriophyoid mites, for example, have an average adult body length ca. $200 \mu \mathrm{m}$, and range from $80 \mu \mathrm{m}$ to $500 \mu \mathrm{m}$ (Lindquist, 1996). The smallest eriophyoid mites normally only have a single egg per female at any one time (Gondim \& Morales, 2003) and their males are smaller than the females (Colwell, 2000). These mites, however, are not egg-parasitoids but freeliving organisms that feed on plant tissue. There is no convincing explanation why these organisms achieve a level of body miniaturization not matched by insects, although it is plausible that the markedly different structure of the brain and the simplicity of their behaviour (Polilov, 2005) along with reduction of locomotory muscles due to passive wind dispersal and lack of need to move around on their host plants might account for this phenomenon.

ACKNOWLEDGEMENTS. R.G. Beutel (Friedrich-SchillerUniversität, Jena) introduced me to the anatomy of the smallest insects, arranged for Discheramocephalus brucei sectioning in his lab, and was my academic host during the year of my Alexander von Humboldt tenure in his lab where this study began. M. Sörensson (Lund, Sweden) introduced me to Ptiliidae, called my attention to the paper by Dybas (1980) with the only North American record of Discheramocephalus, hosted me during my two visits to Lund and commented on the early draft of a part of this paper. S.B. Peck and J. Kukalová-Peck (both Ottawa, Canada) collected and made available FIT samples from Bolivia, which contained specimens of two new Discheramocephalus species. L. Deharveng and A. Bedos (Paris, France) made available Ptiliidae from their Berlese samples collected in Indonesia, which contained new species of Discheramocephalus. B.D. Gill (Ottawa, Canada) accompanied me during the fieldwork in Cameroon, which resulted in the discovery of two more new Discheramocephalus species. E. Hintelmann (Munich, Germany) funded my fieldwork in Cameroon through a scientific foundation, which she had established at the Zoologische Staatssammlung München in memory of her late husband R.J.H. Hintelmann (http://www.zsm.mwn.de/events/wiss_preise.htm). L. Masner (CNCI, Ottawa) called my attention to the original microscope slide in CNCI with the egg-enclosed females and dwarf male of Errolium sp. (Figs 105-106). F. Beaulieu, J. Cumming, J. Huber and J. O'Hara (all CNCI, Ottawa) provided insights into what the smallest body size in insects might be. S.B. Peck, J. Huber and H. Douglas (Canadian Food Inspection Agency, Ottawa) commented on parts of the MS prior to its submission. An anonymous reviewer called my attention to Johnson's (2007) recent paper with the description of Discheramocephalus; thus I narrowly avoided overlooking it and introducing a generic synonym. The help of these individuals is warmly acknowledged.

\section{REFERENCES}

Alexander R.M. 1996: Biophysical problems of small size in vertebrates. In Miller P.J. (ed.): Miniature Vertebrates. The Implications of Small Body Size. The Proceedings of a Symposium Held at the Zoological Society of London on $11^{\text {th }}$ and $12^{\text {th }}$ November 1994. Oxford University Press, Oxford, pp. 3-14. 
Beutel R.G., Pohl H. \& Hünefeld F. 2005: Strepsipteran brains and effects of miniaturization (Insecta). Arthropod Struct. Devel. 34: 301-313.

Colwell R.K. 2000: Rensch's rule crosses the line: convergent allometry of sexual size dimorphism in hummingbirds and flower mites. Am. Nat. 156: 495-510.

Crowson R.A. 1981: The Biology of the Coleoptera. Academic Press, London, $802 \mathrm{pp}$.

DAHMS E. 1984: Revision of the genus Melittobia (Chalcidoidea: Eulophidae) with the description of seven new species. Mem. Queensl. Mus. 21: 271-336.

DoutT R.L. \& Viggiani G. 1968: The classification of the Trichogrammatidae (Hymenoptera: Chalcidoidea). Proc. Calif. Acad. Sci. (4th Ser.) 35: 477-586.

DozIER H.L. 1932: Description of new Mymarid egg parasites from Haiti and Puerto Rico. J. Dept. Agric. Puerto Rico 16: $81-91$.

Dybas H.S. 1980: The smallest beetles (Coleoptera: Ptiliidae). Florida Department of Agriculture and Consumer Service, Division of Plant Industry; Entomology Circular 218: 1-4.

Ellington C.P. 1999: The novel aerodynamic of insect flight: applications to micro-air vehicles. J. Exp. Biol. 202: 3439-3448.

ENock F. 1896: Discovery of the males of Prestwichia aquatica, Lubbock. Entomol. Mon. Mag. 32: 183.

ENOCK F. 1898: Notes on the early stages of Prestwichia aquatica, Lubbock. Entomol. Mon. Mag. 34: 152-153.

Faisal A.A., White J.A. \& Laughlin S.B. 2005: Ion-channel noise places limits on the miniaturizartion of the brain's wiring. Curr. Biol. 15: 1143-1149.

Gondim M.G.C. \& DE Morales G.J. 2003. Life cycle of Retracrus johnstoni Keifer (Acari: Phytoptidae). Neotrop. Entomol. 32: 197-201.

GrebenNikov V.V. 2008: Discheramocephalini, a new pantropical tribe of featherwing beetles (Coleoptera: Ptiliidae) with horizontally perforated mesoventral keels: description of two new genera, eight new species, key, and phylogenetic analysis. Syst. Entomol. 33 (in press).

Grebennikov V.V. \& Beutel R.G. 2002: Morphology of the minute larva of Ptinella tenella, with special reference to effects on miniaturisation and the systematic position of Ptiliidae (Coleoptera: Staphylinoidea). Arthropod Struct. Devel. 31:157-172.

Gregory T.R. 2001: Coincidence, coevolution, or causation? DNA content, cell size, and the C-value enigma. Biol. Rev. 76: $65-101$.

Gregory T.R. 2007: Animal Genome Size Database. Available from URL: http://www.genomesize.com, accessed/downloaded April 21, 2008.

Grissell E.E. \& Schauff M.E. 1997: Chapter 3. Chalcidoidea. In Gibson G.A.P., Huber J.T. \& Wooley J.B. (eds): Annotated Key to Genera of Nearctic Chalcidoidea (Hymenoptera). NRC Research Press, Ottawa, pp. 45-116.

Hadley A. 2006: CombineZ, version 5. Published by the author. Available from URL: http://www.hadleyweb.pwp blueyonder.co.uk/CZ5/combinez5.htm, accessed/downloaded November 21, 2006.

HaLl E.W. 1999: Generic revision of the tribe Nanosellini (Coleoptera: Ptiliidae: Ptiliinae). Trans. Am. Entomol. Soc. 125: 39-126.

Hall E.W. 2005: Chapter 11.2. Ptiliidae Erichson, 1845. In Beutel R.G. \& Leschen R.A.B. (eds): Coleoptera. Vol. 1: Morphology and Systematics (Archostemata, Adephaga, Myxophaga, Polyphaga partim). Handbook of Zoology, Vol.
IV, Arthropoda, Part II, Insecta. Walter De Gruyter, Berlin, pp. 251-261.

Hanken J. \& WaKe D.B. 1993: Miniaturization of body size: organismal consequences and evolutionary significance. Annu. Rev. Ecol. Syst. 24: 501-519.

HorRidge G.A. 1956: The flight of very small insects. Nature 178: $1334-1335$.

Ivanova-KaZAS O.M. 1950: Adaptation to parasitism in embryonic development of Prestwichia aquatica (Hymenoptera). Zool. Zh. 29: 530-544 [in Russian].

Ivanova-KaZAS O.M. 1961: Essays on the Comparative Embryology of Hymenoptera. Leningrad University Press, Leningrad, 266 pp. [in Russian].

Johnson C. 1971: Some Ptiliidae from the Philippine, Bismarck and Solomon Islands (Insecta, Coleoptera). Steenstrupia 2: 39-47.

Johnson C. 2007: Studies on Ptiliidae (Col.) from the Solomon Islands, 1. Entomol. Mon. Mag. 143: 213-226.

Johnston J.S., Ross L.D., Beani L., Hughes D.P. \& KathiRiTHAMBY J. 2004: Tiny genomes and endoreduplication in Strepsiptera. Insect Mol. Biol. 13: 581-585.

KAAS J.H. 2000: Why is brain size so important: design problems and solutions as neocortes gets bigger or smaller. Brain and Mind 1: 7-23.

LAWRENCE J.F. 1999: The Australian Ommatidae (Coleoptera: Archostemata): new species, larva and discussion of relationships. Invertebr. Taxon. 13: 369-390.

LindQuist E.E. 1996: External anatomy and systematics. External anatomy and notation of structures. In Lindquist E.E., Sabelis M.W. \& Bruin J. (eds): Eriophyoid Mites: Their Biology, Natural Enemies and Control. Elsevier, Amsterdam, pp. 3-31.

Masner L. \& Huggert L. 1989: World review and keys to genera of the subfamily Inostemmatinae with reassignment of the taxa to the Platygastrinae and Sceliotrachelinae (Hymenoptera: Platygastridae). Mem. Entomol. Soc. Canada 147: $1-214$.

MOCKFORD E.L. 1997: A new species of Dicopomorpha (Hymenoptera: Mymaridae) with diminutive, apterous males. Ann. Entomol. Soc. Am. 90: 115-120.

Novotny V. \& WiLson M.R. 1997: Why are there no small species among xylem-sucking insects? Evol. Ecol. 11: 419-437.

NuzZaCi G. \& Alberti G. 1996: Internal anatomy and physiology. In Lindquist E.E., Sabelis M.W. \& Bruin J. (eds): Eriophyoid Mites: Their Biology, Natural Enemies and Control. Elsevier, Amsterdam, pp. 101-150.

Pennacchio F. \& Strand M.R. 2006: Evolution of developmental strategies in parasitic Hymenoptera. Annu. Rev. Entomol. 51: 233-258.

Polilov A.A. 2005: Anatomy of the feather-winged beetles Acrotrichis montandoni and Ptilium myrmecophilum (Coleoptera, Ptiliidae). Zool. Zh. 84: 181-189 [in Russian].

Polilov A.A. 2007: Miniaturization-related structural features of Mymaridae. In Rasnitsyn A.P \& Gokhman V.E. (eds): Studies on Hymenopteran Insects. KMK Scientific Press, Moscow, pp. 50-64 [in Russian].

ReNSCH B. 1948: Histological changes correlated with evolutionary changes of body size. Evolution 2: 218-230.

SöRENSSON M. 1997: Morphological and taxonomical novelties in the world's smallest beetles, and the first Old World record of Nanosellini (Coleoptera: Ptiliidae). Syst. Entomol. 22: 257-283.

Received August 31, 2007; revised and accepted January 2, 2008 